\title{
Analysis of several techno-functional and sensory attributes upon egg allergen ingredient substitution by blood plasma powder in sponge cake
}

\author{
TAMÁS CSURKA* ${ }^{*}$, FANNI SZÜCS, BARBARA CSEHI, \\ LÁSZLÓ FERENC FRIEDRICH and KLÁRA PÁSZTOR-HUSZÁR
}

\begin{abstract}
Department of Livestock Products and Food Preservation Technology, Institute of Food Science and Technology, Hungarian University of Agriculture and Life Sciences, Ménesi str. 43-45, H-1118, Budapest, Hungary
\end{abstract}

\section{CONFERENCE FULL PAPER}

Received: June 8, 2021 • Accepted: August 9, 2021

Published online: August 31, 2021

(C) 2021 The Author(s)

\begin{abstract}
Animal blood is a by-product, which can be utilized in a value-adding way instead of being wasted. Allergen substitution is an obvious possibility because many properties of blood plasma are similar to egg white. Techno-functional and sensory attributes (water activity, moisture content, colour and texture related properties) were measured by instrumental methods. The allergenic egg powder can be substituted by non-allergenic blood plasma powder in sponge cakes, but the change in the ingredient has an effect on hardness and tolerating compressive stress until the breaking. In the case of water activity and moisture content, sponge cakes with blood plasma were as desirable as sponge cakes with egg.
\end{abstract}

\section{KEYWORDS}

allergen substitution, animal blood, animal by-product, product development, sustainability

*Corresponding author. E-mail: csurka.tamas@uni-mate.hu 


\section{INTRODUCTION}

Animal blood and separated blood fractions are valuable resources, which are mostly disposed of as hazardous waste (Csurka et al., 2020). If blood is utilized with value-added further processing, it causes environmental, economic, and nutritional benefits as well as can be a tool of sustainability (Ofori and Hsieh, 2014). Consumers also prefer foods from sustainable systems (Floros et al., 2010). Proteins like blood plasma proteins which have not been used for human consumption so far will have an important role in the near future because of the absolute and relative overpopulation and approaching protein deficiency (Godfray et al., 2010).

Egg is an allergenic, essential food ingredient in bakery products because of its solubility, heat coagulation, foaming, and emulsifying properties (Shepherd and Yoel, 1976). It is hard to substitute egg white in bakery products, but blood plasma may be a good alternative for consumers allergic to egg.

Animal blood plasma not only holds opportunities for the meat industry, but it is already used in bakery products: fresh, frozen and spray-dried plasma has a similar effect in texture and appearance of cakes to egg white in similar form and amount (Johnson et al., 1979; Lee et al., 1991). Plasma proteins become denatured at lower temperatures than the major egg white protein (ovalbumin). $\gamma$-globulin is the most heat-stable and fibrinogen is the most heat-sensitive protein in the blood plasma. The foam stability of plasma is similar to that of egg white, but egg white foam is more stable. Plasma fractions, serum albumin, fibrinogen and $\alpha$-globulin have a good foaming capacity and stability. In egg white, globulins are the only protein fraction with good foaming properties. Plasma and plasma proteins are better emulsifiers than egg white and egg white proteins (Raeker and Johnson, 1995). However, according to different researches, plasma is still better than other binders like meat powders, gelatine, wheat gluten, isolated soy protein and combination of sodium alginate and calcium carbonate (Lu and Chen, 1999) and all the blood proteins (globins, serum albumin, haemoglobin) are better emulsifiers than egg (ovalbumin) (Caldironi and Ockerman, 1982).

The protein content of bovine blood plasma is about $7.9 \%$, in which the immunoglobulins represent $4.2 \%$, albumins $3.3 \%$ and fibrinogen $0.4 \%$ (Howell and Lawrie, 1983). According to another research, plasma proteins contain globular proteins (about 60\% albumins and 40\% globulins) and around 3-4\% fibrinogen (Putnam, 2012). Proteins are concentrated in all dried, powdered products. The composition of proteins in the case of blood plasma powder are about $50 \%$ albumin, 15\% $\alpha$-globulin, 15\% $\beta$-globulin and 15\% $\gamma$-globulin (Makara et al., 2016). The composition of blood plasma naturally depends on the animal species and the parameters of the separation technology. There is difference between the plasma of different animal species (Lynch et al., 2017).

It is important to draw attention to food safety requirements of blood plasma utilization. As modern countries regulated, fresh blood has to be handled in a closed system, blood from a limited number of animals can be stored in one container at one time before veterinary examination. The blood of a healthy animal is sterile. At the same time, it can be contaminated from the technology, slaughterhouse staff and the environment in case of the smallest hygienic non-compliance, for instance coagulase positive Staphylococcus aureus, Escherichia coli or Salmonella (Deák et al., 2006; Makara et al., 2016). A good sampling plan has to contain heavy metal analysis, in particular of lead, cadmium and Mercury. Amount of microorganism in blood can be kept below $2.5 \times 10^{5} \mathrm{CFU} \mathrm{mL} \mathrm{m}^{-1}$ by the end of 3 days of storage at $2-3^{\circ} \mathrm{C}$ with proper 
hygiene. After the separation blood plasma should contain a relatively low number, approx. $1 \times 10^{3} \mathrm{CFU} \mathrm{mL} \mathrm{m}^{-1}$ of bacteria. For the easy handling and long minimal durability time, plasma is dried and powdered (usually concentrated and spray dried at around $55^{\circ} \mathrm{C}$ to keep plasma properties intact). The dried plasma contains only $2.5 \%$ water, which does not favour microorganisms (Kowalski et al., 2011). So, plasma powder is a safe raw material, but product, in which plasma powder is used, should be made safe as well for instance by heat-treatment and adequate packaging technology. Besides, acryl amide formation and other synergetic and divergent effects between compounds of final products should be considered.

Fifty-two to seventy w/w\% (per whole blood mass) plasma can be produced during the separation of whole blood depending on the technology and the product requirements (Ockerman and Hansen, 1988). Plasma usually does not contain the blood cells so it does not contain the haemoglobin from the erythrocytes either. The colour of plasma is not red like fresh whole blood and has no iron taste and blood smell. It is mostly not water-clear due to the residual haemoglobin but it is light-brown or pale pink. If the colorization of the final product made with blood plasma is not preferred, it can be improved by decolorization of the raw blood plasma. The $\mathrm{pH}$ of raw plasma is 6.9 , the water content of raw plasma is 91.53 $\mathrm{w} / \mathrm{w} \%$ and the ash content of raw plasma is $0.66 \mathrm{w} / \mathrm{w} \%$. The tea-coloured, decolorized plasma has $7.04 \mathrm{pH}, 92.64 \mathrm{w} / \mathrm{w} \%$ water content and $1.53 \%$ ash content. The protein content decreases from $5.97 \mathrm{w} / \mathrm{w} \%$ to $4.61 \mathrm{w} / \mathrm{w} \%$ during the decolourization process (Makara et al., 2016). High salt content of blood plasma powder (about $15 \mathrm{w} / \mathrm{w} \%$ ) must be considered when setting plasma powder levels of the recipes, because the salt content of egg white is about $0.31 \mathrm{w} / \mathrm{w} \%$ and the salt content of whole egg is about $0.2 \mathrm{w} / \mathrm{w} \%$. Egg white has $12.8 \mathrm{w} / \mathrm{w} \%$, egg yolk has $16.1 \mathrm{w} / \mathrm{w} \%$ and whole egg has $9.45 \mathrm{w} / \mathrm{w} \%$ protein content (Rodler, 2006). Fiftyfour to fifty-five w/w\% of egg white is albumin. Egg yolk proteins contain $14 \%$ serum albumin, 41\% glycoprotein and 45\% immunoglobulin (Jolivet et al., 2008). Comparison of essential amino acid composition of blood and egg fractions and meat myosin are shown in Table 1.

The aim of this study is to substitute egg as an allergen by blood plasma in sponge cake. For this purpose sponge cakes were made with egg by traditional method and with egg powder as well as with blood plasma powder by industrial method and these samples were investigated. Traditional sponge cake is hard to compare with the other two sample groups, but it is very interesting to check which one is closer to the traditional sponge cake from the other two sample groups. Consumers are often looking for the familiar, traditional products and a product which is more similar to the traditional one is more desirable. In this research techno-functional and sensory attributes were measured by instrumental methods. These attributes were the following: water activity, dry matter content, texture (chewiness, hardness) and colour. The product development with allergen substitution is successful if the sponge cake, which contains blood plasma powder instead of egg powder, is more similar to the traditional sponge cake or most properties of the blood plasma powdered sponge cake are similar to those of the sponge cakes made with egg or egg powder. The scope of this paper is to compare these three sample groups (industrial sponge cake with egg powder; industrial sponge cake with whole blood plasma powder; traditional "hand made" sponge cake) based on several techno-functional attributes, which are important in the case of a product development and to provide information for subsequent investigations. 
Table 1. Essential amino acid, cysteine and arginine content of different blood fractions and isolates as well as myosin of meat (for comparison) in mass percent per total protein content (Based on Gorbatov, 1988; Ockerman and Hansen, 1988; Wang et al., 1997; Makara et al., 2016; Sorapukdee and

Narunatsopanon, 2017; Attia et al., 2020)

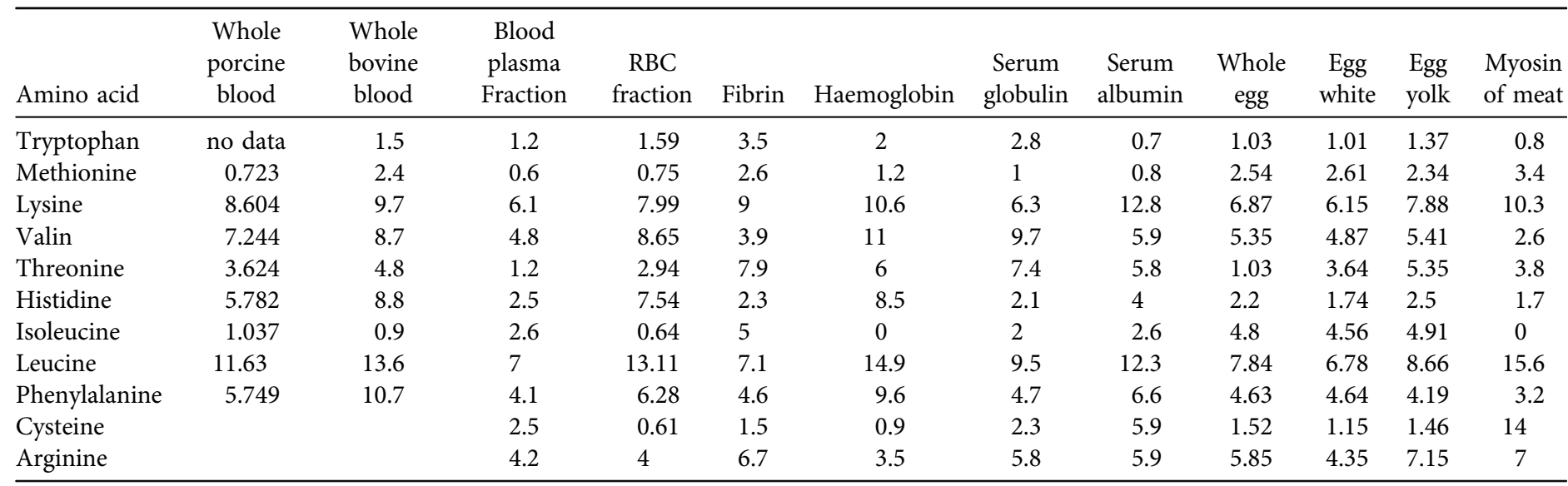




\section{MATERIAL AND METHODS}

\section{Material}

Sample groups of sponge cakes were prepared according to three different recipes, which are shown in Table 2.

Egg powder was provided by Capriovus Kft., Hungary and plasma powder 70B was obtained from Sonac Burgum B.V., Netherlands.

\section{Methods}

Determination of the recipe. The aim was to substitute allergenic egg protein by blood plasma protein. At the same time, fat content of egg has been substituted as well with sunflower oil, which does not have a strong flavour. Water content of egg was replaced by water in the case of each recipe. Thus the sponge cake matrix surrounding the proteins was closely the same as with egg. Raw material specifications and food nutrition database (USDA, 2018) were used for calculating the recipe. We calculated with average $M$ sized eggs, which are $58 \mathrm{~g}$ of weight.

Sponge cake preparation. In the case of "hand made" cakes egg white and egg yolk were separated. Egg yolk was mixed with $1 / 3$ of the sugar, and egg white was whipped with $2 / 3$ of the sugar, then the two parts were softly mixed with the sifted flour. In the case of industrial cakes, ${ }^{1}$ ingredients were mixed well with jilk paste (bakery product emulsifier ingredient), then a foamy mass was made from the mixture by a household mixer. Sponge cake batter was filled into a baking sheet. Sponge cakes were baked at $180^{\circ} \mathrm{C}$ for $20 \mathrm{~min}$ in a convection oven. Sponge cakes were stored for four days, because fresh bakery products are expected to be stored for maximum four days before consumption. The storage conditions corresponded to the average expected home

Table 2. Ingredients' mass $[\mathrm{g}]$ in recipes of different investigated products

\begin{tabular}{lccc}
\hline Ingredients & $\begin{array}{c}\text { Traditional "hand made" } \\
\text { sponge cake }\end{array}$ & $\begin{array}{c}\text { Sponge cake with } \\
\text { egg powder }\end{array}$ & $\begin{array}{c}\text { Sponge cake with whole } \\
\text { blood plasma powder }\end{array}$ \\
\hline Fine flour (g) & 23.7 & 23.47 & 23.31 \\
Crystal sugar of normal & 18.96 & 18.78 & 18.65 \\
$\quad$ particle size (g) & & & \\
Salt (g) & 0.47 & 0.47 & 0.47 \\
Egg (g) & 56.87 & - & - \\
Egg powder (g) & - & 13.15 & - \\
Sodium bicarbonate (g) & - & 1.88 & 1.87 \\
Jilk paste (g) & - & 0.94 & 0.93 \\
Water (g) & - & 41.31 & 41.41 \\
Blood plasma powder $(\mathrm{g})$ & - & - & 8.39 \\
Sunflower oil (g) & - & - & 4.97 \\
\hline
\end{tabular}

\footnotetext{
"Industrial cake" means that the method of production is similar to the industrial method, however, not prepared in a large volume but in small quantities in a laboratory.
} 
storage of fresh bakery products: at room temperature in imperfectly sealed (folded) plastic bag. More samples were baked from the same sample groups on consecutive days to eliminate the change in room humidity.

Water activity measurement. Water activity was measured by Novasina LabMaster-aw neo type instrument (Novasina AG, Switzerland) that requires very small sample amounts and can fully control the temperature between 0 and $60{ }^{\circ} \mathrm{C}$ during the measurement. Measurements were performed at room temperature to control the integrity of samples for relevant data collection.

Moisture content measurement. Three to five g samples, measured by Kern ABJ-NM/ABS-N (Kern \& Sohn GmbH, Germany) analytical balance, were put into open Petri dishes. Then the samples were dried at $120^{\circ} \mathrm{C}$ until constant mass in a laboratory drying oven (Labor Müszeripari Müvek, Hungary). Samples were cooled in a desiccator then their residual mass was measured by the analytical balance. Each sample variety was measured in triplicate.

Colour measurement. Minolta CR-400 (Konica Minolta, INC., Japan) chroma meter was used for the reflection colour measurement. The measurement is based on the fact that any colour can be generated by the mixture of three, defined by light wavelength. The ratio of these three different wavelength lights are plotted in a coordinate system called CIELAB colour space. The colour coordinates can be numbered making colours analyzable.

The instrument was calibrated with a standard white etalon. Each sample was measured three times. Measured attributes are the following: redness/greenness $\left(\mathrm{a}^{\star}\right)$, yellowness/blueness $\left(b^{\star}\right)$ and brightness $\left(\mathrm{L}^{\star}\right)$.

Texture measurement. Texture of sponge cakes was measured by Stable Micro System (SMS) TA.XT Plus texture analyzer (Stable Micro System, United Kingdom). A computer controlled the movement of the upper rod. Different probes are helping measurements with different shear, compressive and torsional stresses in different directions lasting different times while behaviour of samples was investigated.

Sponge cake samples had upward widening cylindrical shape with $5 \mathrm{~cm}$ basis diameter and an average height of $10 \mathrm{~cm}$. The probe was a p/75v steel cylinder plate, which started to press the sample with $0.002 \mathrm{~N}$ force. The extent of the load was $40 \%$ of sample height. The pre-test speed of the probe was $10 \mathrm{~mm} / \mathrm{s}$ and test speed and post-test speed $0.5 \mathrm{~mm} / \mathrm{s}$. "Hold until time" type compression measurement method was used with $30 \mathrm{~s}$ compressing time. Then the sample relaxed. Sampling frequency was 50/s. Each sample was measured three times.

Crust hardness was calculated from the force, which caused $40 \%$ deformation in the sample height, and the extent of this deformation. Cake flexibility was calculated from the ratio of original height and relaxed height of muffins after 30 s $40 \%$ deformation.

Statistical analysis. Measurement results were evaluated by IBM SPSS statistic v25 (IBM Corp., Armonk, NY) and Microsoft Excel 365 version: 2010 (build: 13328.20356) software. To detect the effect of raw material and storage time on redness-greenness, yellowness-blueness, brightness and dry matter content in the first analysis and on crust hardness and cake flexibility in the second analysis, we carried out multivariate analysis of variance (MANOVA), that can compare the means of different sample groups of related variables. According to Levene's test, the homogeneity of variances was slightly violated $(P<0.05)$. The normality of residuals was checked by Shapiro-Wilk test $(P>0.05)$. The value of the unexplained variance 
rate (Wilks's lambda) was evaluated. The homogeneous groups were separated by Tukey HSD post hoc test $(P=0.05)$.

\section{RESULTS AND DISCUSSION}

Water activity of samples, which is shown in Table 3, was relatively stable. The greatest change occurred in the traditional "hand made" sponge cake. According to the MANOVA, storage time after baking was not a significant factor but the type of the cake was considered as a significant factor. Tukey post hoc test could separate two groups: traditional "hand made" and cakes with plasma powder were in the first group and cakes with egg powder were in the second group.

Moisture content, which is shown in Table 4, was relatively stable as well in the case of these samples. Storage time was not identified as a significant parameter by MANOVA. Type of sponge cake was a slightly significant parameter. Tukey post hoc test could separate two groups: traditional sponge cake samples and samples made with plasma powder were in the first group and samples with plasma powder and the ones with egg powder were in the second group. Thus, samples with plasma powder were classified into both groups.

There was no significant difference between sample groups with different storage times, but sample type has a significant effect on the measured lightness and blueness-yellowness based on the results of colour measurement. Samples made with blood plasma powder were the darkest and traditional sponge cakes were the lightest. In the case of blueness-yellowness, sponge cakes made with blood plasma powder had the lowest value and sponge cakes made with egg powder had the highest value. However, the nominal difference between the previous values was very small. Redness-greenness of different sample groups was very similar (Table 5).

In the case of hardness, the results of which are shown in Table 6, measured values were hardly evaluable because of the great standard deviation. There were too many overhanging plots to eliminate. Normality of the unstandardized residuals could not be verified. However, the

Table 3. Measured water activity [-] values of different type samples in case of different storage time [day]

\begin{tabular}{lccc}
\hline Sample type & $\begin{array}{c}\text { Storage time after } \\
\text { baking [day] }\end{array}$ & $\begin{array}{c}\text { Mean of water } \\
\text { activity [-] }\end{array}$ & $\begin{array}{c}\text { Std. deviation of water } \\
\text { activity [-] }\end{array}$ \\
\hline Sponge cake with egg powder & 0 & 0.9172 & 0.0511 \\
& 1 & 0.8969 & 0.0223 \\
Traditional "hand made" & 2 & 0.9026 & 0.0153 \\
sponge cake & 3 & 0.9083 & 0.0211 \\
& 0 & 0.8424 & 0.0243 \\
Sponge cake with whole & 1 & 0.8839 & 0.0161 \\
blood plasma powder & 2 & 0.9012 & 0.0057 \\
& 3 & 0.8819 & 0.0037 \\
& 1 & 0.8583 & 0.0206 \\
& 2 & 0.8812 & 0.0112 \\
& 3 & 0.8833 & 0.0039 \\
\hline
\end{tabular}


Table 4. Measured water content [w/w\%] values of different type samples in case of different storage time [day]

\begin{tabular}{lccc}
\hline $\begin{array}{l}\text { Storage time } \\
\text { after baking } \\
\text { [day] }\end{array}$ & Sample type & $\begin{array}{c}\text { Mean of moisture } \\
\text { content [w/w\%] }\end{array}$ & $\begin{array}{c}\text { Std. deviation of } \\
\text { moisture content } \\
\text { [w/w\%] }\end{array}$ \\
\hline 0 & Sponge cake with egg powder & 0.324 & 0.0409 \\
& Traditional "hand made" sponge cake & 0.322 & 0.0358 \\
1 & Sponge cake with whole blood plasma powder & 0.304 & 0.0306 \\
& Sponge cake with egg powder & 0.341 & 0.0749 \\
& Traditional "hand made" sponge cake & 0.294 & 0.0352 \\
& Sponge cake with whole blood plasma powder & 0.301 & 0.0412 \\
& Sponge cake with egg powder & 0.341 & 0.0379 \\
3 & Traditional "hand made" sponge cake & 0.325 & 0.0339 \\
& Sponge cake with whole blood plasma powder & 0.314 & 0.014 \\
& Sponge cake with egg powder & 0.359 & 0.0427 \\
& Traditional "hand made" sponge cake & 0.283 & 0.0330 \\
& Sponge cake with whole blood plasma powder & 0.319 & 0.0156 \\
\hline
\end{tabular}

Table 5. Measured colour attributes $\left(\mathrm{L}^{*}-\right.$ lightness $[-], \mathrm{a}^{*}-$ redness-greenness $[-], \mathrm{b}^{*}-$ blueness-yellowness [-]) values of different type samples in case of different storage time [day]

\begin{tabular}{|c|c|c|c|c|}
\hline $\begin{array}{l}\text { Colour } \\
\text { attribute }\end{array}$ & $\begin{array}{l}\text { Storage time } \\
\text { after baking } \\
\text { [day] }\end{array}$ & Sample type & $\begin{array}{c}\text { Mean } \\
\text { of colour } \\
\text { attributes [-] }\end{array}$ & $\begin{array}{c}\text { Std. } \\
\text { Deviation }\end{array}$ \\
\hline \multirow[t]{12}{*}{$L^{*}$} & \multirow[t]{3}{*}{0} & Sponge cake with egg powder & 73.03 & 5.58 \\
\hline & & Traditional "hand made" sponge cake & 80.98 & 0.77 \\
\hline & & Sponge cake with whole blood plasma powder & 66.64 & 1.29 \\
\hline & \multirow[t]{3}{*}{1} & Sponge cake with egg powder & 69.95 & 0.99 \\
\hline & & Traditional "hand made" sponge cake & 79.93 & 0.78 \\
\hline & & Sponge cake with whole blood plasma powder & 67.16 & 0.79 \\
\hline & \multirow[t]{3}{*}{2} & Sponge cake with egg powder & 71.40 & 2.89 \\
\hline & & Traditional "hand made" sponge cake & 79.38 & 2.81 \\
\hline & & Sponge cake with whole blood plasma powder & 67.62 & 2.73 \\
\hline & \multirow[t]{3}{*}{3} & Sponge cake with egg powder & 73.92 & 0.82 \\
\hline & & Traditional "hand made" sponge cake & 80.19 & 0.16 \\
\hline & & Sponge cake with whole blood plasma powder & 67.66 & 3.00 \\
\hline \multirow[t]{9}{*}{$a^{*}$} & \multirow[t]{3}{*}{0} & Sponge cake with egg powder & 0.32 & 1.34 \\
\hline & & Traditional "hand made" sponge cake & 0.48 & 0.71 \\
\hline & & Sponge cake with whole blood plasma powder & 1.10 & 0.34 \\
\hline & \multirow[t]{3}{*}{1} & Sponge cake with egg powder & 1.14 & 0.01 \\
\hline & & Traditional "hand made" sponge cake & 1.15 & 0.97 \\
\hline & & Sponge cake with whole blood plasma powder & 0.98 & 0.01 \\
\hline & \multirow[t]{3}{*}{2} & Sponge cake with egg powder & 1.10 & 1.60 \\
\hline & & Traditional "hand made" sponge cake & 1.00 & 0.72 \\
\hline & & Sponge cake with whole blood plasma powder & 1.04 & 0.65 \\
\hline
\end{tabular}


Table 5. Continued

\begin{tabular}{|c|c|c|c|c|}
\hline $\begin{array}{l}\text { Colour } \\
\text { attribute }\end{array}$ & $\begin{array}{l}\text { Storage time } \\
\text { after baking } \\
\text { [day] }\end{array}$ & Sample type & $\begin{array}{c}\text { Mean } \\
\text { of colour } \\
\text { attributes [-] }\end{array}$ & $\begin{array}{c}\text { Std. } \\
\text { Deviation }\end{array}$ \\
\hline \multirow{15}{*}{$b^{*}$} & \multirow[t]{3}{*}{3} & Sponge cake with egg powder & 0.38 & 0.99 \\
\hline & & Traditional "hand made" sponge cake & 0.87 & 0.01 \\
\hline & & Sponge cake with whole blood plasma powder & 1.13 & 0.29 \\
\hline & \multirow[t]{3}{*}{0} & Sponge cake with egg powder & 35.77 & 1.18 \\
\hline & & Traditional "hand made" sponge cake & 29.88 & 3.00 \\
\hline & & Sponge cake with whole blood plasma powder & 28.25 & 1.78 \\
\hline & \multirow[t]{3}{*}{1} & Sponge cake with egg powder & 36.86 & 0.22 \\
\hline & & Traditional "hand made" sponge cake & 31.53 & 3.07 \\
\hline & & Sponge cake with whole blood plasma powder & 31.56 & 0.33 \\
\hline & \multirow[t]{3}{*}{2} & Sponge cake with egg powder & 36.49 & 3.45 \\
\hline & & Traditional "hand made" sponge cake & 32.69 & 2.48 \\
\hline & & Sponge cake with whole blood plasma powder & 28.75 & 2.20 \\
\hline & \multirow[t]{3}{*}{3} & Sponge cake with egg powder & 35.63 & 3.05 \\
\hline & & Traditional "hand made" sponge cake & 32.50 & 0.71 \\
\hline & & Sponge cake with whole blood plasma powder & 27.54 & 0.83 \\
\hline
\end{tabular}

difference between samples with plasma powder and the group of other samples is clear and great.

In the case of the other texture measurement, a significant parameter was not found either, because conditions for the MANOVA were not met. But if breaking force values were eliminated, a significant parameter was found for compressive stress at the time of breaking, namely the sample type. Samples with plasma powder could be significantly separated from

Table 6. Measured hardness $\left[\mathrm{N} \mathrm{mm}^{-1}\right]$ values of different type samples in case of different storage time [day]

\begin{tabular}{lcrc}
\hline $\begin{array}{l}\text { Storage time } \\
\text { after baking } \\
\text { [day] }\end{array}$ & Sample type & $\begin{array}{c}\text { Mean of } \\
\text { hardness } \\
{\left[\mathrm{N} \mathrm{mm}^{-1}\right]}\end{array}$ & $\begin{array}{c}\text { Std. deviation } \\
\text { of hardness } \\
{\left[\mathrm{N} \mathrm{mm}^{-1}\right]}\end{array}$ \\
\hline 0 & Sponge cake with egg powder & 5.38 & 0.002 \\
& Traditional "hand made" sponge cake & 3.78 & 1.429 \\
1 & Sponge cake with whole blood plasma powder & 33.85 & 4.985 \\
& Sponge cake with egg powder & 5.42 & 1.682 \\
& Traditional "hand made" sponge cake & 4.91 & 1.183 \\
2 & Sponge cake with whole blood plasma powder & 31.16 & 0.195 \\
& Sponge cake with egg powder & 5.85 & 1.782 \\
3 & Traditional "hand made" sponge cake & 3.99 & 0.773 \\
& Sponge cake with whole blood plasma powder & 23.44 & 5.024 \\
& Sponge cake with egg powder & 4.97 & 1.442 \\
& Traditional "hand made" sponge cake & 4.99 & 0.808 \\
& Sponge cake with whole blood plasma powder & 27.04 & 6.629 \\
\hline
\end{tabular}


Table 7. Value of measured breaking force $[\mathrm{N} \mathrm{s}]$ and compressive stress at the time of breaking $[\mathrm{mPa}]$ in the case of different type samples and different storage time [day]

\begin{tabular}{lcccc}
\hline \multirow{2}{*}{ Parameter } & Sample type & $\begin{array}{c}\text { Storage time after } \\
\text { baking [day] }\end{array}$ & Mean & $\begin{array}{c}\text { Std. } \\
\text { deviation }\end{array}$ \\
\hline Breaking force $[\mathrm{N} \mathrm{s}]$ & Sponge cake with egg powder & 0 & 97.68 & 12.784 \\
& & 1 & 107.17 & 47.461 \\
& & 2 & 168.40 & 31.098 \\
& Traditional "hand made" & 3 & 161.82 & 97.522 \\
& sponge cake & 0 & 139.16 & 72.028 \\
& & 1 & 235.79 & 44.348 \\
& & 2 & 164.59 & 67.957 \\
& Sponge cake with whole & 3 & 278.95 & 87.9 \\
Compressive stress at the & blood plasma powder & 0 & 192.19 & 17.105 \\
time of breaking [mPa] & & 1 & 148.41 & 53.869 \\
& & 2 & 164.91 & 59.825 \\
& Sponge cake with egg powder & 3 & 190.06 & 41.269 \\
& & 0 & 5.25 & 0.113 \\
& & 1 & 5.29 & 1.687 \\
& & 2 & 8.45 & 1.022 \\
& Traditional "hand made" & 3 & 7.69 & 3.374 \\
& sponge cake & 0 & 7.6 & 2.968 \\
& & 1 & 12.84 & 3.394 \\
& & 2 & 8.83 & 4.189 \\
& & 3 & 13.38 & 4.435 \\
& & 0 & 11.1 & 1.112 \\
& Sponge cake with whole & 1 & 11.31 & 2.853 \\
& blood plasma powder & 2 & 10.51 & 2.562 \\
& & 3 & 9.92 & 3.428 \\
\hline
\end{tabular}

other sample groups based on the compressive stress at the time of breaking. Measured values of braking force and compressive stress at the time of breaking can be found in Table 7.

Texture measurement has to be repeated more times in a future investigation because texture of sponge cake is not homogeneous enough and results a large standard deviation in the case of three parallel samples.

\section{CONCLUSION}

Based on this research the allergenic egg powder can be substituted by non-allergenic blood plasma powder in sponge cakes, but the change in the ingredient has an effect on some properties. If instrumentally measured sensory attributes of different types of cakes were compared, cakes made with plasma powder were found harder and more firm, more suitable for instance for cake sculpting or producing harder cakes, which can withstand higher load from fillings. Colour of sponge cakes made with blood plasma powder was significantly different from the other sample groups, but this nominal difference was not great, samples were relatively similar to the human 
eye. Water activity stayed near the critical 0.86 value, which is the lowest water activity value where human-pathogenic microorganisms (coagulase positive Staphylococcus aureus) can produce toxins (Deák et al., 2006). Moisture content also remained at a desirable level. Product development was successful. However, this topic needs further investigations: organoleptic quality has to be validated by a sensory analysis according to the GSP, because high salt content of blood plasma powder can cause non-compliances beside inadequate fillings or flavouring. Salted caramel, salted hazelnut and salted chocolate flavouring are especially adequate for the natural cake with plasma powder. Besides that, high temperature during baking favour formation of acryl amid. Acryl amid content has to be investigated in future studies.

\section{ACKNOWLEDGEMENTS}

This research was supported by the Hungarian University of Agriculture and Life Sciences, Doctoral School of Food Sciences.

\section{REFERENCES}

Attia, Y.A., Al-Harthi, M.A., Korish, M.A., and Shiboob, M.H. (2020). Protein and amino acid content in four brands of commercial table eggs in retail markets in relation to human requirements. Animals, 10(3): 406.

Caldironi, H.A. and Ockerman, H.W. (1982). Incorporation of blood proteins into sausage. Journal of Food Science, 47(2): 405-408.

Csurka, T., Pásztor-Huszár, K., Tóth, A., Pintér, R., and Friedrich, L.F. (2020). Investigation of the effect of trisodium-citrate on blood coagulation by viscometric approach. Progress in Agricultural Engineering Sciences, 16(S2): 19-26. https://doi.org/10.1556/446.2020.20003.

Deák, T., Kiskó, G., Maráz, A., and Mohácsiné, F.C. (2006). Élelmiszer-mikrobiológia. Mezögazda.

Floros, J.D., Newsome, R., Fisher, W., Barbosa-Cánovas, G.V., Chen, H., Dunne, C.P., German, J.B., Hall, R.L., Heldman, D.R., and Karwe, M.V. (2010). Feeding the world today and tomorrow: the importance of food science and technology. Comprehensive Reviews in Food Science and Food Safety, 9: 572-599.

Godfray, H.C.J., Beddington, J.R., Crute, I.R., Haddad, L., Lawrence, D., Muir, J.F., Pretty, J., Robinson, S., Thomas, S.M., and Toulmin, C. (2010). Food security: the challenge of feeding 9 billion people. Science, 327(5967): 812-818.

Gorbatov, V.M. (1988). Collection and utilization of blood and blood proteins for edible purposes in the USSR. Advances in Meat Research (USA), 5: 167-195.

Howell, N.K. and Lawrie, R.A. (1983). Functional aspects of blood plasma proteins. I. Separation and characterization. Journal of Food Technology, 18: 747-762.

Johnson, L.A., Havel, E.F., and Hoseney, R.C. (1979). Bovine plasma as a replacement for egg in cakes. Cereal Chem, 56(4): 339-342.

Jolivet, P., Boulard, C., Chardot, T., and Anton, M. (2008). New insights into the structure of apolipoprotein B from low-density lipoproteins and identification of a novel YGP-like protein in hen egg yolk. Journal of Agricultural and Food Chemistry, 56(14): 5871-5879.

Kowalski, Z., Makara, A., and Banach, M. (2011). Blood plasma and hemoglobin production process. Chemik, 65(5): 466-475. 
Lee, C.C., Johnson, L.A., Love, J.A., and Johnson, S. (1991). As an egg white substitute in cakes'. Cereal Chem, 68(1): 100-104.

Lu, G.H. and Chen, T.C. (1999). Application of egg white and plasma powders as muscle food binding agents. Journal of Food Engineering, 42(3): 147-151.

Lynch, S.A., Mullen, A.M., O'Neill, E.E. and García, C.Á. (2017). Harnessing the potential of blood proteins as functional ingredients: a review of the state of the art in blood processing. Comprehensive Reviews in Food Science and Food Safety, 16(2): 330-344.

Makara, A., Kowalski, Z., Fela, K., and Generowicz, A. (2016). Utilization of animal blood plasma as example of using cleaner technologies methodology. Technical Transaction. Environment Engineering, 1-Ś/2016: 87-96.

Ockerman, H.W. and Hansen, C.L. (1988). Animal by-product processing. VCH, Weinheim; Chichester: Horwood.

Ofori, J.A. and Hsieh, Y.H.P. (2014). Issues related to the use of blood in food and animal feed. Critical Reviews in Food Science and Nutrition, 54(5): 687-697.

Putnam, F. (Ed.) (2012). The plasma proteins V3: structure, function, and genetic control. Elsevier.

Raeker, M.Ö. and Johnson, L.A. (1995). Thermal and functional properties of bovine blood plasma and egg white proteins. Journal of Food Science, 60(4): 685-690.

Rodler, I. (2006). Új tápanyagtáblázat. Medicina Könyvkiadó, Budapest.

Shepherd, I.S. and Yoel, R.W. (1976). Cake emulsions. Ch. 5. In: Friberg, S. (Ed.), Food emulsions, pp. 215275.

Sorapukdee, S. and Narunatsopanon, S. (2017). Comparative study on compositions and functional properties of porcine, chicken and duck blood. Korean Journal for Food Science of Animal Resources, 37(2): 228.

USDA, United States Department of Agriculture, Agricultural Research Service, Nutrient Data Laboratory (2018). USDA National Nutrient Database for Standard Reference, Release 29. https://fdc.nal.usda.gov/.

Wang, L., Flores, R.A., and Johnson, L.A. (1997). Processing feed ingredients from blends of soybean meal, whole blood, and red blood cells. Transactions of the ASAE, 40(3): 691-697.

Open Access. This is an open-access article distributed under the terms of the Creative Commons Attribution 4.0 International License (https://creativecommons.org/licenses/by/4.0/), which permits unrestricted use, distribution, and reproduction in any medium, provided the original author and source are credited, a link to the CC License is provided, and changes - if any - are indicated. (SID_1) 